\title{
Beyond voice: Audience-making and the work and 'architecture of listening' as new media literacies
}

\author{
Jim Macnamara \\ University of Technology Sydney
}

\begin{abstract}
Considerable attention in communication, media, and social science scholarship is focused on voice which is considered an important form of social capital and necessary for social equity. Studies have extensively examined access to communication technologies and various forums such as the public sphere, as well as media literacy required to have a voice. Despite continuing concern over a 'digital divide', the emergence of Web 2.0-based 'new media', also referred to as 'social media', is seen as an empowering development contributing to a democratisation of voice. However, based on two studies of online public consultation and critical analysis of the literature on voice and listening, this article argues that two important corollaries of voice, as it is commonly conceptualised, are overlooked. To matter, as Nick Couldry says it should, voice needs to have an audience and, second, audiences must listen. While considerable attention is paid by mass media to creating, maintaining, and engaging audiences, comparatively little attention is paid to audiences and listening in discussions of new media and social media. In an environment of proliferating channels for speaking coinciding with demassification and 'fragmentation' of audiences, engaging audiences and the work of listening have become problematic and are important media literacies required to make voice matter.
\end{abstract}

Keywords: Voice; listening; audience-making; media literacy; citizen media; social media

\section{Introduction - The value and limits of voice}

Considerable attention has been paid to public speaking and human voice since the early Western civilisations of ancient Greece and Rome where rhetoric - the art of speaking persuasively - became recognised as one of the foundational liberal arts based on the writings and oratory of Plato, Aristotle, Cicero and Quintilian (Atwill 1998; Kennedy 1994). Rhetoric was also studied and developed as early as 500 BC in Islamic societies of North Africa (Bernal 1987) and in China (Lu 1998).

In contemporary societies, rhetoric remains one of the major traditions of human communication scholarship and practice identified by Robert Craig (1999) and discussed in a number of communication texts (e.g. Craig and Muller 2007; Griffin 2009; Littlejohn and Foss 2008). In liberal political theory, voice is identified as a fundamental element of democratic society. As well as the rhetorical voice of political leaders, expression of vox populi - the 'voice of the people' - is recognised as essential for the effective functioning of democracy. Despite criticisms that the focus of politics is predominantly speaking (Bickford 1996; Dobson 2010), democratic governments today routinely use the internet to invite citizens to 'voice' their concerns and questions - such as the UK's Number 10 Web site which invites citizens to submit videos or sign e-petitions (http://www.number10.gov.uk/take-part) and the Australian federal government's open invitation to citizens to 'Have your say' (http://australia.gov.au/have-your-say). A Google Web search of the phrase 'have your say' brought up 348 million references and a search on 'giving a voice' yielded 163 million references as at late-2011. As 'Listening Project'1 researcher Tanja Dreher notes: 'in much research and advocacy, there is a strong emphasis on the democratic potential of voice, representation, speaking up and talking back' $(2009,446)$ [italics added]. 
When citizens experience a lack or loss of voice, a number of scholars point to significant social, cultural and political problems. For instance, Charles Husband (2000) and others have drawn attention to the lack of voice in any meaningful sense afforded to ethnic minorities and argued that this constitutes oppression and injustice. Feminism similarly has identified lack of voice available to women as a social inequity negatively impacting the status and identity of women in many societies, and fostered a tradition of debate focussed on speaking, voice and representation (Butler 1999; Kristeva 1980; Spender 1980; Tuchman 1978; Weatherall 2002).

Rhetorical theory pays some attention to the related concept of audience. Beyond its recent pejorative meaning which implies manipulation of people by the persuasive oratory of speakers, rhetoric in its original Platonic and Aristolean conceptualisation, as well as its subsequent use in classical Greece and Rome, requires consideration of the audience. In contemporary times, Donald Bryant has emphasised that rhetoric is not simply oratory expressing the views of the speaker, but is adapted and tailored to the audience $(1953,123)$. However, this could be described as audiencing as discussed by John Fiske (1994) and Yvonna Lincoln $(1997,2001)$ which is principally a technique of tailoring voice to be most persuasive for particular audiences and is a far cry from focussing on the construction of audience and listening in an open engaged way.

Notwithstanding some recognition of voice as 'the implicitly linked practices of speaking and listening' (Couldry 2009a, 580), there is overwhelming advocacy and what could be described as valorisation of voice in the narrow sense of speaking in much scholarly and popular literature and significantly less discussion of how the important corollaries of audiences and listening are operationalised in order to make voice matter. Susan Bickford (1996) pointed this out in the context of politics in her landmark text, The Dissonance of Democracy: Listening, Conflict and Citizenzhip in which she noted the lack of attention to listening in democratic politics and argued that political interactions take place in a context of conflict and inequality that affects not only who gets to speak, but particularly who gets attention and who gets listened to.

For the most part, audiences are assumed to listen. Even more presumptuously, in mediated public communication, audiences are largely assumed to exist. They are 'imagined communities' as discussed by Benedict Anderson (1991). Unlike public speaking to physically assembled groups of people, media audiences cannot be seen or heard by speakers. Therefore they are doubly assumed and imagined - assumed and imagined to exist and assumed and imagined to listen. These assumptions may have some justification in relation to mass media in which circulation, marketing, and research departments devote considerable resources to assembling, engaging, measuring and maintaining audiences. However, these twin assumptions are problematic and require reconsideration in a 'new media' environment characterised by 'demassification', 'audience fragmentation' and 'atomisation' (Anderson, C. 2006; Deuze 2005; Jenkins 2006; Rosen 2009) occurring at the same time as rapidly increasing use of citizen and social media allegedly affording voice.

This article seeks to build on the notable work of pioneering scholars such as Susan Bickford and recent critiques by identifying and examining two further important issues for voice to matter in contemporary societies - the need to create and maintain audiences and the 'work of listening' which become all the more challenging in an environment of simultaneous 'audience fragmentation' and proliferating media channels and speakers. As well as critically reviewing literature in the field, this analysis is informed by two studies of online public communication - one conducted by the author (Macnamara 2010a), and one undertaken at the MIT Deliberatorium (Iandoli, Klein, and Zolla 2009; Klein 2007; Klein, Malone, Sterman, and Quadir 2006). The findings indicate that skills and resources not currently 
identified as part of media literacy are required to engage audiences and accomplish listening in new media environments and the conclusions present some examples of how notions of media literacy need to be expanded.

\section{The literature on voice and listening}

The growing body of literature on voice and listening will not be extensively summarised here, as it has been ably reviewed in the recent themed edition of Continuum on listening in 2009 (vol. 23, no. 4) and in texts such as Nick Couldry's (2010) Why Voice Matters and Leslie Baxter's (2011) Voicing Relationships: A Dialogic Perspective. However, some key terms need to be defined in order to proceed in this analysis with a common language and key concepts require explanation, particularly those related to online communication or in which online communication involves particular practices that affect listening and voice.

Voice is conceptualised in this discussion as not only the human verbal act of speaking, but also human communication through other actions such as writing and online participation, voting, protesting, and various other forms of polemic such as political artworks, graffiti, and so on. Furthermore, this discussion notes the problematic nature of the concept of audience when it is used to denote passive receivers of information, and recoils from this view, employing instead a contemporary cultural studies notion of audiences as active participants in communication (Hall 1973; Lievrouw and Livingstone 2002, 10; Silverstone 2007, 107) albeit existing within 'interpretative communities' (Fish 1980) and influenced by context. In Oscar Gandy's typology of four types of audiences - audience as victims, audience as commodity, audience as consumers, and audience as citizens (Gandy 2002, 448) - this study is particularly concerned with the latter. It is also important to recognise that audiences are discursive constructs, largely conjured into existence by authors, media institutions and marketers (Ang 1996) and that they can be over-imagined and over-assumed. However, notwithstanding these limitations and necessary clarifications of the term 'audience' ${ }^{2}$, in this analysis it is argued that the term does important work serving as a corollary of speaking and voice and representing potential listeners and sites of listening.

Listening is used here not in a loose general way, but in a specific sense. In the International Journal of Listening, Ethel Glenn (1989) has identified 50 different definitions of listening. However, drawing on Glenn and other scholars who have studied listening such as Sara Lundsteen (1979), the International Listening Association has adopted a definition that emphasises 'receiving and constructing meaning from, and responding to spoken and/or nonverbal messages' (cited in Purdy and Borisoff 1997, 6) [italics added]. Discussing listening in the context of media and public communication, Charles Husband says that listening requires paying attention to another's voice expressed in a text ${ }^{3}$ of some type $(2009,441)$. Drawing on Barthes, Axel Honneth (2007) goes further and argues that listening requires recognition of what another or others have to say, whether verbally or in some other form. Charles Husband further proposes that people have a right to be understood as a 'qualifying complementary right' to the right to communicate (1996), although he has noted that this 'third-generation human right' ${ }^{4}$ is a utopian goal $(2000,208)$.

In recent examinations of listening, Kate Crawford (2009) and Nick Couldry (2009a) argue that listening is a useful metaphor for online engagement, although Crawford notes that 'listening is not a common metaphor for online activity ... "speaking up" has become the dominant metaphor for participation in online spaces' $(2009,526)$ - an issue that this research explored. 
Based on listening literature in relation to both interpersonal and public communication, listening can be seen to involve a substantive level of human cognitive engagement with the expressed views of another or others involving attention, recognition, interpretation to try to discover meaning, ideally leading to understanding, as well as responding in some way - not simply being present at or observing some communicative activity. Thus, listening is an active rather than passive activity involving considerable effort and responsibility.

Nick Couldry reflects widespread concern over voice in saying that there is a 'crisis of voice' in modern societies and in neoliberal societies in particular (2008a, 389; 2009a, 581). In several journal articles and in his text Why Voice Matters (Couldry 2010), he argues that neoliberalism denies voice to many citizens. Conversely, affording voice is widely discussed in scholarly and professional literature as empowering. However, drawing on the work of Philip Bobbit (2003), Couldry says that even when citizens have an ability to speak, neoliberalism's privileging of the market economy means that the voices of most people become an 'externality' to discussion and discourse in which economic values prevail. Commenting on initiatives to give citizens increased opportunities to have a voice in democratic politics, Bobbit argues that unless governments listen and there are mechanisms to process and act on citizens' inputs, 'there will be more public participation in government but it will count for less' (2003, 234). Couldry agrees and advocates that 'we do not just need a participatory democracy; we need a participatory democracy where participation matters' (2009b, n.p.). To matter, voice must as a corollary have someone (an audience) who listens that is, really listens as defined in the literature.

Citing German social theorist Axel Honneth (1995) and studies of UK citizen engagement in politics (Couldry, Livingstone, and Markham 2007), Couldry reported that 'the real issue about the ... long-term decline in engagement in formal electoral politics in the UK and elsewhere ... was not so much a "motivation crisis" on the part of citizens ... the real issue was a "recognition crisis"' (2008b, 16). Nancy Fraser also has discussed recognition as an important element in terms of social justice. She notes that some social actors are less than full members of society and less able to participate as peers because of an inequitable distribution of resources, with one of those resources being recognition $(2000,113)$.

Research and public debate by members of 'The Listening Project' (http://www.thelisteningproject.net) have sought to foreground the role of listening in communication and draw attention to the 'labour of listening' and what that might entail, as well as the 'politics of voice' (Bickford 1996; Couldry 2009a) and the 'politics of recognition' (The Listening Project 2009). Drawing on political theory and postcolonial feminism, Listening Project researcher Tanja Dreher says that societies need to learn 'listening across difference'. This concept draws attention to the social, cultural, political and ideological barriers to attention, recognition, understanding, and response, and shifts focus and responsibility from the marginalised and voiceless 'on to institutions and conventions which enable and constrain receptivity and response' (2009, 456). As well as moving discussion beyond the simplistic and sometimes tokenistic strategy of affording voice to addressing how voice can be made to matter, this line of research opens up an a fertile and under-explored terrain in which of array of institutional, political, structural, and ideological features loom large and invite examination.

There are also important ethical aspects of listening, as recently discussed in a special issue of the International Journal of Listening in which Pat Gehrke (2009) called for a broader methodological approach in studying listening, drawing on phenomenology, dialogism and relational dialectics as well as democratic political theory as a way to incorporate ethics. The ethics of listening is not specifically discussed here, but this analysis does employ a 
multidisciplinary perspective and its recommendations address ethical as well as practical concerns.

Of particular relevance to this analysis, Couldry extends discussion of voice and listening to new forms of digital media. He says that digital media provide 'the capacity to tell important stories about oneself - to represent oneself as a social, and therefore potentially political agent - in a way that is registered in the public domain' (2008a, 386). He argues that, in contrast with the 'hidden injuries of media power' that are caused by institutionalised mass media which offer limited access to citizens (Couldry 2001), 'digital storytelling in principle represents a correction of those latter hidden injuries since it provides the means to distribute more widely the capacity to tell important stories' (Couldry 2008a, 386). Many texts such as Dan Gillmor's We The Media (2006) and Clay Shirky's Here Comes Everybody (2008) celebrate this alleged democratising potential of digital media. But is the claimed democratisation of voice really affording voice that matters?

\section{The missing audience}

Mass society and mass media theory which evolved from the 1920s led to the concepts of mass audiences and mass markets which have been pre-eminent paradigms in media research and the public sphere throughout much of the twentieth century (Curran and Gurevitch 2000; Hoggart 2004). Because of expensive and often patented technologies of production and distribution, and strict regulatory environments including licensing, media became increasingly controlled by monopolies and oligopolies in the period referred to by Mark Poster (1995) as the First Media Age.

This concentration of media production and distribution, combined with large-scale marketing and promotion undertaken by major movie studios, broadcast networks, and newspaper publishers, resulted in citizens being coerced and even forced into mass viewing, listening and reading of content. For instance, Chris Anderson reported that, in 1954, 74 per cent of Americans clustered around TV sets to watch I Love Lucy every Sunday night (2006, 29). By the end of the twentieth century, as Ben Bagdikian (2004) reported, five corporations - Time Warner, Disney, News Corporation, Viacom and Bertelsmann - dominated the output of daily newspapers and magazines, broadcasting, books and movies worldwide, reaching 'audiences' totalling billions. Commercial deals still wrap up exclusive media rights to Formula One Grand Prix, the summer and winter Olympics, the American Super Bowl, and other major events creating, for short moments, large numbers of viewers, listeners, and readers.

However, as far back as 1927, John Dewey argued that thinking of people as a mass or aggregate is not useful in understanding how communication or society works (Grossberg et al., 2006, 390). In 1958, noted British sociologist Raymond Williams wrote in Culture and Society: 'There are in fact no masses; only ways of seeing people as masses' $(1958,289)$. Even when people are forced to become part of a large 'viewing public', they remain agentic individuals each interpreting and sometimes resisting content and messages. Furthermore, when given a choice, they are disinclined to engage in communication en masse and become what Jay Rosen (2006) calls 'the people formerly known as the audience', a shift that will be examined in detail in a moment. Theories of mass communication to mass audiences conceptualised as stable, passive groups of receivers are now rejected by most scholars as satisfactory explanations of how public communication takes place (Abercrombie \& Longhurst 1998; Ruddock 2007; Sparks 2006).

Despite the problematic nature of audiences and mass audiences in particular, traditional media succeeded in assembling audiences through (1) limited choice brought about by 
regulated technology resulting in cosy commercial oligopolies; and (2) major investments in marketing and promotion to attract and hold listeners, viewers, and readers, referred to as 'audience-making' by James Ettema and D. Charles Whitney (1994). The importance of audience-making was highlighted in the late 1970s by Dallas Smythe in what became known as the 'blindspot debate' in which Smythe argued that the ideologies of critical studies grounded in neomarxism and cultural studies blinded researchers to the economics of advertising-supported commercial media in which audiences are the main 'commodities' produced and traded by mass media (Smythe 1977).

Recently, Fernando Bermejo (2009) has taken up this issue in an analysis of 'audience manufacture' in media industries adding that, while media nominally sell space and time, 'what is being sold is attention' (136). He points to an active 'audience production market' in which mass media seek to maintain and measure audiences (139) and in which audiences do 'work' or 'labour' (136). While critics of capitalism see this work or labour primarily as consumption, others such as Jhally and Livant (1986) point out that it involves listening which is an essential element in the process of communication and necessary to make voice matter.

In short, while Dewey, Williams and others were correct in challenging mass audiences as stable groups of listeners, traditional media have been at least somewhat successful in ensuring the existence of audiences and gaining their attention to listen to those afforded voice.

In contrast, while celebrating the democratisation of media in what Mark Poster (1995) calls the Second Media Age, media and marketing scholars are increasingly becoming aware of the significantly more problematic nature of audiences when mass media are bypassed by millions of micro-media such as blogs, microblogging (e.g. Twitter), social networks (e.g. Facebook and MySpace), and video and photo sharing sites (e.g. YouTube and Flickr). What are referred to as 'new media' and 'social media' have provided plurality and plenty in voice, but lead to the breakup of mass audiences pre-assembled through traditional media concentration, regulation, and mass marketing - a phenomenon referred to by various authors as 'demassification', 'fragmentation', or 'atomisation' (Anderson, C. 2006; Deuze 2005; Jenkins 2006; Rosen 2009). In discussing mass media audiences, Mark Deuze says 'at the beginning of the $21^{\text {st }}$ century ... it is possible to argue the temporary (and imagined) existence of such mass audiences has vanished - save the televised pseudo-events of the Super Bowl in the United States' and other manufactured events which he cites (2005). Henry Jenkins quotes a researcher from Forrester who summarised this trend saying 'monolithic blocks of eyeballs are gone. In their place is a perpetually shifting mosaic of audience micro-segments' $(2006,66)$. In relation to the public sphere which has become a mediated space in modern societies (Corner 2007, 212; Louw 2005, 140), a number of scholars note the increasing proliferation of 'public sphericles' because of the explosion in citizen and social media (Fraser 1992; Gitlin 1998; Goode 2005; Howley 2007; Warner 2002). Some argue that these fragments of the public sphere have become 'digital enclaves' (de Sola Pool 1990) and 'echo chambers' (Leonard 2004).

As Ien Ang points out in relation to television, but which can be applied more broadly, audience is not an ontological given, but rather it is a socially constituted and discursively constructed concept (1991, xi, 3). In the case of traditional media, the concept gains form through the considerable attention and resources devoted to assembling and retaining readers, viewers and listeners, and formal systems of measuring and tracking them. However, in the case of social media or citizen media, audiences - and therefore listening - are unlikely to exist without attention to the work of audience-making and the work of audiences. 


\section{Audience-making - a new form of media literacy}

For the growing number of citizens who have access to and use the internet, particularly interactive sites referred to as 'new media' and 'social media', gaining a voice that matters is predicated on simultaneously gaining an audience who listens. In the shift from central, professionalised media to social media and social networks, the significant but underestimated role of audience-making is transferred from large media organisations with dedicated circulation and marketing departments and agencies with specialist marketing and promotion skills and substantial budgets, to small organisations and individuals who most often do not possess either. Without the resources and skills required for audience-making, many social media users will not realise the promise of voice tantalisingly offered and celebrated by cyberoptimists such as Harold Rheingold (2002), Yochai Benkler (2006) and Henry Jenkins (2006). Visitor data from internet monitoring firms indicate that a substantial proportion of bloggers, microbloggers, YouTube video producers, podcasters, and social networkers on the internet have very small audiences. For instance, Technorati (2011) has reported that almost half (48 per cent) of the 133 million blogs it tracks receive fewer than 1,000 visitors per month, and just two per cent have more than 100,000 visitors per month. Many social media users have only a few readers or viewers and, therefore, are largely talking to themselves.

As Penny O'Donnell stated in the special listening issue of Continuum, "the expectation of 'easy listening' in online media is misplaced and counterproductive. It diverts attention away from fundamental communicative challenges associated with digital media, including audience fragmentation” (2009, 504). Similarly, in discussing digital media and youth, Peter Levine has noted that 'the Net does not give everyone an equal audience, let alone a large one' (2008, 124). Levine concludes that strategies for building audiences are essential in the case of user-generated digital media $(2008,119)$.

Such strategies require an expansion of our understanding of media literacy and digital literacy. As in politics, discussion of these literacies is predominantly focussed on content production and distribution - i.e. on speaking. To gain a voice that matters in an increasingly online digital world, media literacy needs to include the knowledge and skills to acquire, retain, and engage online 'visitors', 'friends', 'followers', 'fans', and subscribers through practices such as linking, hyperlink swapping, search engine optimisation (SEO), and use of RSS (Really Simple Syndication), as well as skills to produce and post content. This suggests a range of additional technical skills relating to attracting and engaging audiences need to be incorporated into digital media literacy education.

Second, in addition to technical skills, media literacy in terms of audience-making can benefit from engagement with marketing and promotion. Levine proposed a number of strategies for students to create audiences for their work including using highly interactive game-like communication environments that are attractive to other youth, marketing youth products as incentives along with online content, and organising face-to-face events to build communities (2008, 131-32). Specialist online marketing and promotion techniques such as Search Engine Optimisation (SEO) are increasingly necessary to gain audiences online because of the sheer volume of content available to search engines. Creative industries such as film and music recognise the need for concerted efforts in audience-making and, as they have moved online, they have turned attention to developing new skills for creating global audiences (see Carey 2009 and Crossfield 2008). While Couldry warns of "self-promotion and 'self-branding"” when they are deployed to advance neoliberal market values (2010,34), a transdisciplinary approach drawing on the fields of marketing, advertising and public relations could 
contribute much to new media literacy by affording skills and techniques for audiencemaking.

\section{The work of listening}

Once an audience is in place to potentially pay attention to, give recognition to, understand and respond to a speaker or speakers, the third element of this triad of communication (along with speaking and audience) is the performance of listening. A number of scholars including Susan Bickford (1996), Axel Honneth (1995, 2007), Charles Husband (2000, 2009), and Tanya Dreher (2009) have drawn attention to the considerable work involved in listening at an interpersonal level. They point out that, among other things, listening requires negotiation of silence, questions and argumentation, dealing with difference, and acceptance of the risk of one's own views being challenged or even proved wrong - hence Susan Bickford's call for 'courageous listening' (Bickford 1996, 153).

In online Web 2.0 media and networks, listening is demonstrated in a number of unique ways such as posting comments (e.g. in blogs and in Wall posts on Facebook); 'liking' Facebook pages; 'following' on Twitter; re-tweeting; voting in some sites; tagging; 'bookmarking' subscribing; and even in 'lurking' ${ }^{5}$ (Crawford 2009). Each of these practices requires some technical knowledge and involves conventions and protocols that need to be understood. These deserve to be further researched and taught as part of digital media literacy for individual citizens, not only at a technical level but as cultural practices of participation.

In addition, listening on a large-scale such as that required for participation in major online forums and online public consultations throws up further challenges beyond the already difficult processes of listening to individuals and in small groups. In the public sphere as discussed by Habermas (1989, 2006) and others (e.g. Corner 2007 and Louw 2005), public communication and representations traditionally involve a relatively small number of 'political actors' such as politicians, political parties, journalists, and various advocates, and take place largely through a quite small and shrinking number of mass media. In such an environment, listening is relatively easy, as the views of political actors and citizens are aggregated at a few sites.

However, with the explosion in new forms of citizen and social media and vast numbers of citizens who produce as well as consume media content - referred to as prosumers by Alvin Toffler $(1970,1980)$ or produsers by Axel Bruns (2008) - listening becomes an altogether new challenge. Today, millions of citizens can potentially send billions of messages through SMS text, e-mail, blogs, social networks, online videos, wikis and online forums. When large-scale speaking is afforded, new strategies of listening are required. Kate Crawford's (2009) categorisation of 'delegated listening' as well as 'background listening' and 'reciprocal listening' is helpful in understanding online listening, and organisational listening in particular, as large government and corporate organisations frequently deploy a range of intermediaries in listening, monitoring and responding roles. These 'agents', as well as direct listening, are considered in the following analysis.

The work of large-scale listening in an online environment is demonstrated in the findings of two studies cited in support of this analysis. The first was a study of online public consultation by the Australian federal government in 2009 (Macnamara 2010a, 2010b, 183 205) which included comparative analysis with the Obama presidential campaign in the US and UK government e-democracy initiatives (UK Cabinet 2009). This study based on depth interviews with senior staff responsible for online public consultation in 11 Australian government departments and agencies and members of the Obama Online Operation (Triple 
O), as well as content analysis of online consultation sites, found nine key barriers to listening and true affordance of citizens' voice in large-scale online interaction. A number of these directly related to the labour of listening including:

- A lack of planning, with social media platforms such as blogs ${ }^{6}$ being selected as sites for citizen engagement without careful analysis of the most relevant or suitable forum (Macnamara 2010b, 186-9);

- A lack of integration of IT, communication and policy considerations and functions which researchers conclude is important. It was found that IT-driven sites were technically sound but not user-friendly or communicative, while communication staff planned for two-way dialogic engagement but lacked technical skills to make sites function well. Furthermore, both types of initiatives were often not articulated to policymaking, with the result that citizens' views had little chance of gaining recognition or influence (Macnamara 2010b, 187).

\section{The architecture of listening}

In addition, it can be concluded from analysis of online public consultation by Australian federal government departments and agencies and experimental research undertaken by the MIT Deliberatorium that the work of listening includes establishing an architecture of listening - a framework with appropriate policies, structures, resources and facilities that enable voice to matter by gaining attention, recognition, consideration and response. The study of online public consultation in Australia (Macnamara 2010b) found:

- Restrictive Public Service policies and procedures in relation to speaking publicly resulted in acknowledgements and responses not meeting online users' expectations and sometimes not occurring at all (190). It would be interesting to explore whether bureaucratic procedures in corporations similarly limit interaction;

- Poor design and navigation made it difficult to find information and interact, as many sites were aligned with the structure of the organisation rather than the interests of users (192-5);

- Moderation policies deleted citizens' comments that contained 'bad language' such as swearing which effectively silenced many by preventing them from speaking in their own voice (195-6);

- There was a focus on government-hosted sites, rather than engagement in existing online communities (196-7). As well as presenting audience-making challenges as discussed previously, this narrowed participation to what Stephen Coleman calls 'managed citizenship' rather than 'autonomous citizenship' (2008, 192), and it denied voice to citizens' who chose to speak in other sites which government officials did not pay attention to;

- There was a lack of resources, including human resources, applied to monitor discussion and respond. No department or agency allocated any additional staff to online engagement sites despite the objective of attracting increased expression of voice (191). As a result, much attempted expression of voice went unattended, unrecognised and effectively unheard; 
- Sense-making tools such as text analysis software applications were not deployed on any of the sites. In reviewing the trials, the Australian Government Information Management Office (AGIMO) identified that text analysis software and other technological aids are needed by institutions and individuals when large-scale voice is activated and large-scale listening is required, as humans simply cannot process, interpret and understand the extensive and diverse discussions that can occur on the internet.

Ongoing experimental research in online communication within a 220-member user community conducted by the Massachusetts Institute of Technology (MIT), initially called The Collaboratorium (Klein 2007) and renamed The Deliberatorium in 2008 (Iandoli, Klein, and Zolla 2009, 70), provides useful insights into the architecture that needs to be established to process large-scale speaking and afford voice. In reporting on an online climate change forum conducted in what was then called The Collaboratorium, Klein et al (2006) identified five key requirements for sense making in online public consultation: (1) careful design of the rules of interaction; (2) 'seeding' of discussions with 'an initial corpus of policy options and pointers' to stimulate discussion; (3) a 'committed community of contributors and expert judges'; (4) voting systems which provide citizens with simple quick ways of contributing; and (5) tools for collating and assessing well-structured arguments. These recommendations provide some foundation stones for an architecture of listening that must be developed for widely-afforded voice to be meaningful.

Klein (2007) who has been extensively involved in the Collaboratorium/Deliberatorium project warns that large-scale interactions to date through online applications such as e-mail, instant messaging, chat rooms, blogs and wikis 'have been incoherent and dispersed, contributions vary widely in quality, and there has been no clear way to converge on wellsupported decisions'. He cites problems in online discussion including a 'low signal to noise ratio', 'balkanisation' as users self-assemble into groups that share the same opinions, 'dysfunctional argumentation', and 'hidden consensus' that is lost in the volume of comments and viewpoints. Also, 'group interactions are all too easily hijacked by a narrow set of "hot" issues or loud voices', according to Klein and Iandoli $(2008,1)$.

In a 2009 paper, Iandoli, Klein and Zolla note that few attempts have been made to support large, diverse and geographically dispersed groups in systematically exploring and coming to decisions about complex and controversial issues $(2009,69)$. They say that, while large-scale online organisation using low-cost technologies has achieved outstanding results in knowledge creation, sharing and accumulation, 'current technologies such as forums, wikis and blogs ... appear to be less supportive of knowledge organisation, use and consensus formation' (70). In short, current online communication tools and approaches are effective in enabling speaking, but when issues are complex or generate widespread argument, Iandoli, Klein and Zolla say 'little progress has been made ... in providing virtual communities with suitable tools and mechanisms for collective decision-making' (70) which requires listening although they did not specifically discuss listening.

Three types of argumentation tools have been identified as important in the MIT Deliberatorium, based on de Moor's and Aakhus' (2006) argumentation support model sharing, funnelling and argumentation tools. In a report of trials conducted by The Deliberatorium, Klein (2007) says that system design should include aids such as articles for users to read to become familiar with issues and for and against views before participating. Further, he says that design should provide 'argument maps' to group and link ideas and arguments on a topic. Third, he says online consultation systems should provide simple tools for users to search, add comments, rate, and vote on articles and ideas, as well as post new 
articles. Fourth, Klein says it is essential to provide immediate feedback to users such as simple 'thank you' acknowledgements of contributions.

This view is supported by experiences from the 2008 Obama election campaign in the US. Technology director of the Democratic National Committee, Ben Self, who was instrumental in the online campaign, says that less than 10 staff processed all online communication with citizens. One of the key strategies that made this possible was the use of 'placeholders' and pre-prepared responses that could be e-mailed or personalised with minimum customisation (Self, pers.comm., 16 February, 2009). Klein (2007) also says that creation and maintenance of a logical 'argument mapping' structure requires editors with experience in argument map creation and harvesting of the best ideas from open discussion to add to argument maps.

Further features and elements for what is proposed here as an 'architecture of listening' in public communication are suggested by Iandoli, Klein and Zolla (2009) which cannot be fully explored here, but which offer concepts for further research. From findings of experimental studies in the MIT Deliberatorium, analysis of online public consultation trials in Australia (Macnamara 2010a, 2010b), and interviews with staff of the Obama Online Operation, some of these additional features of an 'architecture of listening' for large-scale public consultation and communication are schematically presented in Figure 1. In summary, these include:

1. Background reading for those unfamiliar with topics to enable them to gain understanding in order to participate in an informed way;

2. A moderation function to intervene in unacceptable communication such as racism, sexism or vilification;

3. An acknowledgement function (possibly auto-generated) to respond to speakers promptly;

4. A categorisation function to group information and comments into topics or headings so they are easy to find and follow;

5. Editors' summaries to update late-comers to the conversation and condense and clarify large volumes of comment;

6. Collection of comments in a database as a secure and searchable record;

7. Finally, and importantly, an interface with relevant policy advisers and decision-makers so that majority voices and consensus can lead to action and change. 


\section{Government / Organisation}

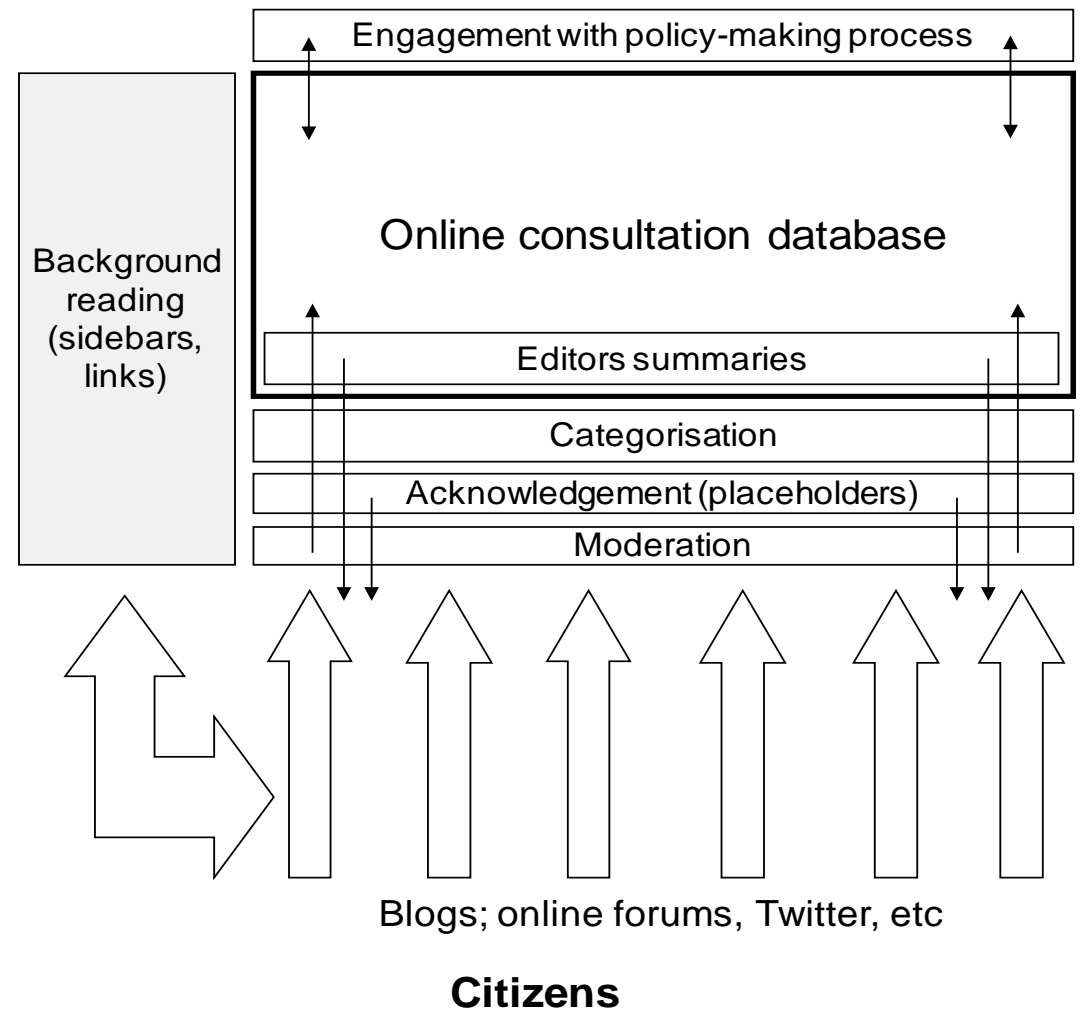

Figure 1. Key elements of an 'architecture of listening' for large-scale public consultation and communication (Macnamara, 2010a, 2010b).

\section{Conclusions}

Increased recognition of the democratic right of voice as encompassing 'being listened to' is to be welcomed. Furthermore, the conceptualisation of listening as comprising attention, recognition, interpretation with a view to understanding, and response, is important for voice to be meaningful and matter. However, in the context of public communication in contemporary societies in which voice is largely mediated, increasingly through Web 2.0enabled social media which democratise voice, there are two important aspects of voice that require recognition and address.

First, to make their voice matter, individuals, groups and organisations engaging in mediated communication need to acquire the knowledge and skills to attract, retain and engage with audiences. In an age of user-generated social media, research and teaching of media literacy needs to expand to include audience-making through the use of digital media skills and online marketing and promotional techniques in order to effectively deploy voice.

Second, the work of listening, challenging on even a small scale, is considerably more complex in large-scale public communication. When thousands or millions of citizens speak publicly, listening needs to overcome cacophony and deal with competition for attention and diversity. To cope, individuals need to develop skills and strategies for selectivity as well as receptivity. Governments, organisations, and companies seeking to communicate with citizens on a large scale need to devote considerable resources to the work to listening including the creation of an architecture of listening. 
While technologies can provide tools to aid listening, such as monitoring, argumentation and text analysis software, the concept of an architecture of listening is not an argument for technological determinism. As reported in the two studies cited, an architecture of listening in organisations requires policies, procedures, human resources and human application to processes of listening by moderators, editors, communication practitioners and policy advisers. An architecture of listening has cultural, institutional, structural and political as well as technological components.

Understanding of the need for and techniques of audience-making by social media users, and the work required for large-scale listening including the need for and composition of an architecture of listening in organisations, are important to afford citizens voice that matters and create a participatory public sphere as well as engagement between organisations and their stakeholders such as employees, members, customers and communities.

\section{References}

Abercrombie, Nicholas, and Brian Longhurst. 1998. Audiences: A sociological theory of performance and imagination. London: Sage.

Anderson, Bendict. 1991. Imagined communities: Reflections on the origin and spread of nationalism (Rev. Ed.). New York and London: Verso. (Original work published 1983)

Anderson, Chris. 2006. The long tail. New York: Hyperion.

Ang, Ien. 1991. Desperately seeking the audience. London: Routledge.

Ang, Ien. 1996. Living room wars: Rethinking media audiences for a postmodern world. New York: Routledge.

Atwill, Janet. 1998. Rhetoric reclaimed: Aristotle and the liberal arts tradition. Ithaca, NY: Cornell University Press.

Bagdikian, Ben. 2004. The new media monopoly. Boston, MA: Beacon.

Baxter, Leslie. 2011.Voicing relationships: A dialogic perspective. London and Thousand Oaks, CA: Sage.

Benkler, Yochai. 2006. The wealth of networks: How social production transforms markets and freedom. New Haven, CT: Yale University Press.

Bermejo, Fernando. 2009. Audience manufacture in historical perspective: From broadcasting to Google. New Media and Society 11, no. 1 \& 2: 133-54.

Bernal, Martin. 1987. Black Athena: The Afroasiatic roots of classical civilisation. Piscataway, NJ: Rutgers University Press.

Bickford, Susan. 1996. The dissonance of democracy: Listening, conflict and citizenship. Ithaca, NY and London: Cornell University Press.

Bobbit, Philip. 2003. The shield of Achilles: War, peace and the course of history. Harmondsworth, UK: Penguin.

Bruns, Axel. 2008. Blogs, Wikipedia, Second Life and beyond: From production to produsage. New York: Peter Lang.

Bryant, Donald. 1953. Rhetoric: Its functions and its scope. Quarterly Journal of Speech 39: 123-40.

Butler, Judith. 1999. Gender trouble: Feminism and the subversion of identity. New York: Routledge.

Carey, Sargent. 2009. Local musicians building global audiences. Information, Communication \& Society 12, no. 4: 469-87.

Coleman, Stephen. 2008. Doing IT for themselves: Management versus autonomy in youth ecitizenship. In Civic life online: Learning how digital media can engage youth, ed. W. Lance Bennett, 189-206. Cambridge, MA: MIT Press.

Corner, John. 2007. Media, power and political culture. In Media studies: Key issues and debates, ed. E. Devereux, 211-30. London: Sage.

Couldry, Nick. 2001. The hidden injuries of media power. Journal of Consumer Culture 1, no. 2: 155-74.

Couldry, Nick. 2008a. Mediatization or mediation? Alternative understandings of the emergent space of digital storytelling. New Media \& Society 10: 373-91. 
Couldry, Nick. 2008b. Media and the problem of voice. In Participation and media production, eds. Nico Carpentier and Benjamin de Cleen, 15-26. Cambridge, UK: Cambridge Scholars Publishing.

Couldry, Nick. 2009a. Commentary: Rethinking the politics of voice. Continuum: Journal of Media \& Cultural Studies 23, no. 4: 579-82.

Couldry, Nick. 2009b. Culture and politics beyond the horizon of neoliberalism. Keynote address to the Australian \& New Zealand Communication Association (ANZCA) conference, Brisbane, July 9.

Couldry, Nick. 2010. Why voice matters, London and Thousand Oaks, CA: Sage.

Couldry, Nick, Livingstone, Sonia, and Markham, Tim. 2007. Media consumption and public engagement: Beyond the presumption of attention. Basingstoke, UK: Palgrave.

Craig, Robert. 1999. Communication theory as a field. Communication Theory 9: 119-61.

Craig, Robert, and Heidi Muller, eds. 2007. Theorising communication: Readings across traditions. Thousand Oaks, CA: Sage Publications.

Crawford, Kate. 2009. Following you: Disciplines of listening in social media. Continuum: Journal of Media \& Cultural Studies 23, no. 4: 525-35.

Crossfield, Jonathon. 2008. Is the internet killing copyright? Nett magazine, October, 77-80.

Curran, James, and Michael Gurevitch. 2000. Mass media and society. $3^{\text {rd }}$ ed. London: Hodder Headline.

de Moor, Aldo, and Mark Aakhus. 2006. Argumentation support: From technologies to tools, Communications of the ACM 49, no. 3: 93-8.

de Sola Pool, Ithiel.1990. Technology without boundaries: On telecommunications in a global age. Cambridge, MA: Harvard University Press.

Deuze, Mark. 2005. Towards professional participatory storytelling in journalism and advertising. http://web.mit.edu/comm-forum/mit4/papers/Deuze.pdf (accessed January 26, 2011).

Dobson, Andrew. 2010. Democracy and nature: Speaking and listening. Political Studies 58, no.4, October, 752-768.

Dreher, Tanja. 2009. Listening across difference: Media and multiculturalism beyond the politics of voice. Continuum: Journal of Media \& Cultural Studies 23, no. 4: 445-58.

Ettema, James, and Charles Whitney, eds. (1994). Audiencemaking: How the media create the audience. London and Newbury Park, CA: Sage.

EUCAP [European Capital Partners]. 2006. Build it, blog it, and they will come. Blog post August 24. http://blog.eucap.com/creative-class/build_it_and_they_will_come.html (accessed March 16, 2010).

Fish, Stanley. 1980. Is there a text in this class: The authority of interpretative communities. Cambridge, MA: Harvard University Press.

Fiske, John. 1994. Audiencing: cultural practice and cultural studies. In Handbook of Qualitative Research, eds. Norman Denzin and Yvonna Lincoln, 189-198. Thousand Oaks, CA: Sage.

Fraser, Nancy. 1992. Rethinking the public sphere: A contribution to the critique of actually existing democracy. In Habermas and the public sphere, ed. C. Calhoun, 109-42. Cambridge, MA: MIT Press.

Fraser, Nancy. 2000. Rethinking recognition. New Left Review 3: 107-36.

Gandy, Oscar. 2002. The real digital divide: Citizens versus consumers. In The handbook of new media, eds. Leah Lievrouw and Sonia Livingstone, 448-60. London: Sage.

Gehrke, Pat. 2009. Introduction to listening, ethics, and dialogue: Between the ear and eye: A synaesthetic introduction to listening ethics. The International Journal of Listening 23, no. 1: 1-6.

Gillmour, Dan. 2006. We the media: Grassroots journalism by the people, for the people. Sebastapol, CA: O’Reilly Media Inc.

Gitlin, Todd. 1998. Public spheres or public sphericles? In Media, ritual and identity, eds. Tamar Liebes and James Curran, 170-73. New York: Routledge.

Glenn, Ethel. 1989. A content analysis of fifty definitions of listening. The International Journal of Listening 3, no. 1: 21-31.

Goode, Luke. 2005. Jürgen Habermas: Democracy and the public sphere. London: Pluto Press. Griffin, Em. 2009. A first look at communication theory. $7^{\text {th }}$ ed. Boston, MA: McGraw-Hill.

Grossberg, Lawrence, Ellen Wartella, D. Charles Whitney, and J. Macgregor Wise. 2006. Media making: Mass media in a popular culture. Thousand Oaks, CA: Sage Publications. 
Habermas, Jürgen. 1989. The structural transformation of the public sphere. Cambridge, UK: Polity. (Original work published 1962)

Habermas, Jürgen. 2006. Political communication in media society: Does democracy still enjoy an epistemic dimension? The impact of normative theory on empirical research. Communication Theory 16, no. 4: 411-26.

Hall, Stuart. 1973. Encoding/decoding. In Culture, media, language, eds. Stuart Hall, Dorothy Hobson, Andrew Lowe, and Paul Willis, 26-7. London: Hutchinson.

Hoggart, Richard. 2004. Mass media in a mass society: Myth and reality. London: Continuum. Honneth, Axel. 1995. The struggle for recognition: The moral grammar of social conflicts. Cambridge, UK: Polity Press.

Honneth, Axel. 2007. Disrespect. Cambridge, UK: Polity Press.

Howley, Kevin. 2007. Community media and the public sphere. In Media studies: Key issues and debates, ed. E. Devereux, 342-60. London: Sage Publications.

Husband, Charles. 1996. The right to be understood: Conceiving the multi-ethnic public sphere. Innovation: The European Journal of Social Sciences 9, no. 2: 205-15.

Husband, Charles. 2000. Media and the public sphere in multi-ethnic societies. In Ethnic minorities and the media, ed. S. Cottle, 199-214. Buckingham and Philadelphia: Open University Press.

Husband, Charles. 2009. Commentary: Between listening and understanding. Continuum: Journal of Media \& Cultural Studies 23, no. 4: 441-43.

Iandoli, Luca, Mark Klein, and Giuseppe Zolla. 2009. Enabling online deliberation and collective decision making through large-scale argumentation: A new approach to the design of an internetbased mass collaboration platform. International Journal of Decision Support System Technology 1, no. 1. Hershey, PA: IGI Global, .

Jenkins, Henry. 2006. Convergence culture: Where old and new media collide. New York: New York University Press.

Jhally, Sut, and Bill Livant. 1986. Watching as working: The valorisation of audience consciousness. Journal of Communication 36, no. 3: 124-43.

Kennedy, George. 1994. A new history of classical rhetoric. Princeton, NJ: Princeton University Press.

Klein, Mark. 2007. The MIT Collaboratorium: Enabling effective large-scale deliberation for complex problems (Working Paper 4679-08). Cambridge MA: MIT Sloan School of Management, December 31. http://ssrn.com/abstract=1085295 (accessed January 26, 2011).

Klein, Mark, and Luca Iandoli. 2008. Supporting collaborative deliberation using a large-scale argumentation system: The MIT Collaboratorium. Cambridge, MA: MIT Sloan School of Management. http://papers.ssrn.com/sol3/papers.cfm?abstract_id=1099082 (accessed October 10, 2011).

Klein, Mark, Thomas Malone, John Sterman, and Iqbal Quadir, I. 2006. The climate collaboratorium: Harnessing collective intelligence to address climate change issues. Cambridge MA: Massachusetts Institute of Technology, June 22. http://cci.mit.edu/collaboratorium.pdf (accessed January 26, 2011).

Kristeva, Julia. 1980. Desire in language: A semiotic approach to literature and art. New York: Columbia University Press.

Leonard, Andrew. 2004. Trapped in the echo chamber. Salon, 3, November 3. http://www.salon.com/tech/col/leon/2004/11/03/echo_chamber (accessed January 26, 2011).

Levine, Peter. 2008. A public voice for youth: The audience problem in digital media and civic education. In Civic life online: Learning how digital media can engage youth, ed. W. Lance Bennett, 110-38. Cambridge, MA: MIT Press.

Lincoln, Yvonna.1997. Self, subject, audience, text: Living at the edge, writing in the margins. In Representation and the text: Reframing the narrative voice, eds. William Tierney and Yvonna Lincoln, 37-54. Albany, NY: State University of New York Press.

Lincoln, Yvonna. 2001. Audiencing research: Textual experimentation and targeting for whose reality? Opinion Papers (120) - Speeches/Meeting Papers (150). Paper presented to Association for the Study of Higher Education annual meeting, Richmond, VA, November 15-18.

Littlejohn, Stephen, and Karen Foss. 2008. Theories of human communication. $9^{\text {th }}$ ed. Belmont, CA: Thomson-Wadsworth.

Lievrouw, Leah and Livingstone, Sonia. 2002. Introduction: The social shaping and Consequences of ICTs. In Handbook of New Media, eds. Leah Lievrouw and Sonia Livingstone, 1-15. London: Sage. 
Louw, Eric. 2005. The media and political process. London: Sage.

Lu, Xing. 1998. Rhetoric in ancient China fifth to third century BCE: A comparison with classical Greek rhetoric. Columbia, SC: University of South Carolina Press.

Lundsteen, Sara. 1979. Listening: Its impact on language and the other language arts. Urbana, IL: ERIC Clearing House on Reading and Communication Skills.

Macnamara, Jim. 2010a. The quadrivium of online public consultation: Policy, culture, resources, technology. Australian Journal of Political Science 45, no. 2: 227-44

Macnamara, Jim. 2010b. The $21^{\text {st }}$ century media (r)evolution: Emergent communication practices. New York: Peter Lang.

O’Donnell, Penny. 2009. Journalism, change and listening practices. Continuum 23, no. 4, 503-17.

Poster, Mark. 1995. The second media age. Cambridge, UK: Polity.

Purdy, Michael, and Deborah Borisoff. 1997. Listening in everyday life: A personal and professional approach. $2^{\text {nd }}$ ed. Lanham, MA: University of America Press.

Rheingold, Howard. 2002. Smart mobs: The next social revolution. Cambridge, MA: Perseus Publishing.

Rosen, Jay. 2006. The people formerly known as the audience. PressThink blog, June 27. http://journalism.nyu.edu/pubzone/weblogs/pressthink/2006/06/27/ppl_frmr.html (accessed January 26, 2011).

Rosen, Jay. 2009. Audience atomization overcome: Why the net erodes the authority of the press. The Huffington Post, April 14. http://www.huffingtonpost.com/jay-rosen/audience-atomizationover_b_157807.html (accessed January 26, 2011).

Ruddock, Andy. 2007. Audiences. London and Thousand Oaks, CA: Sage.

Shirky, Clay. 2008. Here comes everybody: The power of organising without organisations. New York: Penguin Press.

Silverstone, Roger. 2007. Media and morality: On the rise of the mediapolis. Cambridge, UK: Polity Press.

Smythe, Dallas. 1977. Communications: Blindspot of Western Marxism. Canadian Journal of Political and Social Theory 1, no. 3: 1-27.

Sparks, Glen. 2006. Media effects research: A basic overview. $2^{\text {nd }}$ ed. Belmont, CA: Thomson Wadsworth.

Spender, Dale. 1980. Man made language. London: Routledge \& Kegan Paul.

Technorati. 2011. State of the Blogosphere 2010. http://technorati.com/blogging/article/howtechnology-traffic-and-revenue-day/ (accessed October 10, 2011).

The Listening Project. 2009. Listening Futures: Symposium. Macquarie Graduate School of Management, December 7. Sydney.

Toffler, Alvin. 1970. Future shock. New York: Random House.

Toffler, Alvin. 1980. The third wave. New York: William Morrow.

Tuchman, Gaye. 1978. The symbolic annihilation of women by the mass media. In Hearth and home: Images of women and the media, eds. Gaye Tuchman, Arlene Daniels, and James Benet, 3-17). New York: Oxford University Press.

UK Cabinet. 2009. Power of Information Task Force Report. http://www.cabinetoffice.gov.uk/reports/power_of_information.aspx (accessed October 16, 2012).

Warner, Michael. 2002. Publics and counterpublics. Cambridge MA: Zone Books.

Weatherall, Ann. 2002. Gender, language and discourse. Hove, UK: Routledge.

Williams, Raymond 1958. Culture and society. London: Chatto and Windus.

1 The Listening Project is a research collaboration between Australian cultural and media scholars, practitioners and activists interested in the theme of listening(see http://www.thelisteningproject.net).

2 As noted by Roger Silverstone (2007, 107), Sonia Livingstone (2002) and others, a wide range of terms is used in relation to participants in communication including audience, participants, users, consumers, citizens, communicators, producers, players, prosumers (Toffler 1970, 1980), and produsers (Bruns 2008). Almost all terms have been problematised due to their varying definitions and interpretations. Nicholas Abercrombie and Brian Longhurst (1998) and Andy Ruddock (2007) argue that the term audience is useful provided it is understood in an active participative context.

3 Text in this context in meant to include visual and audio content as well as written and printed texts. 
4 The rights to encode and transmit messages and to receive and decode messages on one's own terms are considered to be first and second generation human rights in relation to communication.

5 'Lurking' refers to internet users who visit interactive sites and observe but do not comment or contribute content.

6 The linear reverse chronological order of text in blogs can make finding particular information or following particular topics difficult, although techniques such as 'tag clouds' which highlight and link key themes help user navigation.

* Jim Macnamara PhD, MA, FPRIA, FAMI, CPM, FAMEC is Professor of Public Communication at the University of Technology Sydney and Director of the Australian Centre of Public Communication, positions he took up in 2007 after a 30-year professional career spanning journalism, public relations and media research. He is the author of 12 books including The $21^{\text {st }}$ Century Media (R)evolution: Emergent Communication Practices published by Peter Lang, New York in 2010 and Public Relations Theories, Practices, Critiques published by Pearson Australia in 2012.

\section{Published reference:}

Macnamara, J. 2013. Beyond voice: Audience-making and the work and architecture of listening. Continuum: Journal of Media \& Cultural Studies vol. 27, no. 1, 160-175. 